ISSN 1392-3196 / e-ISSN 2335-8947

Zemdirbyste-Agriculture, vol. 102, No. 3 (2015), p. 335-342

DOI 10.13080/z-a.2015.102.043

\title{
The structure of mating type, metalaxyl resistance and virulence of Phytophthora infestans isolates collected from Latvia
}

\author{
Alice AAV ${ }^{1}$, Ilze SKRABULE², Gunita BIMŠTEINE ${ }^{3}$, Tanel KAART ${ }^{4}$, \\ Ingrid $\mathrm{H}$. WILLIAMS ${ }^{1}$, Eve RUNNO-PAURSON ${ }^{1}$ \\ ${ }^{1}$ Institute of Agricultural and Environmental Sciences, Estonian University of Life Sciences \\ Kreutzwaldi 1, Tartu, 51014, Estonia \\ E-mail: alice.aav@emu.ee \\ ${ }^{2}$ Priekuli Plant Breeding Institute \\ Zinatnes 2, Priekuli 4126, Latvia \\ ${ }^{3}$ Institute of Soil and Plant Sciences, Latvia University of Agriculture \\ Lielâ 2, Jelgava 3001, Latvia \\ ${ }^{4}$ Institute of Veterinary Medicine and Animal Sciences, Estonian University of Life Sciences \\ Kreutzwaldi 1, Tartu 51004, Estonia
}

\begin{abstract}
Potato late blight, caused by the oomycete Phytophthora infestans (Mont.) de Bary, is one of the most serious potato (Solanum tuberosum L.) diseases, causing considerable yield loss in potato production worldwide, including Latvia. At present, the data on the population characteristics of $P$. infestans in Latvia is sparse. Therefore, the main aim of this study was to collect new data on Latvian isolates of $P$. infestans, to determine the main characteristics of the pathogen, particularly mating types, metalaxyl resistance and virulence with Black's differential set of potato genotypes containing resistance (R) genes R1-R11.

During 2010-2012, 181 isolates of $P$. infestans were collected from 23 potato fields, from 13 locations in Latvia. Out of 181 isolates tested, $52.5 \%$ were A1, $43.1 \%$ - A 2 and $4.4 \%$ - self-fertile mating type. Of 116 isolates screened for resistance to metalaxyl, $25.9 \%$ were resistant, $19.8 \%$ - intermediate and $54.3 \%$ - sensitive. More than $80 \%$ of isolates were virulent to R1, R3, R4, R7, R10 and R11, while 33\% or fewer isolates were virulent to R5, R8 and R9. The least frequent was virulence against R9 in $24 \%$ of isolates. Our study revealed that the Latvian population of $P$. infestans is diverse. The proportion of mating types and the occurrence of both A1 and A2 in the same field indicate the possibility of sexual recombination in Latvian fields. Thus, it is very important to keep the crop rotation system, to prevent soil contamination with long-living oospores. The Latvian population of $P$. infestans shares many similarities with other European populations, which suggests gene flow between populations.
\end{abstract}

Key words: mating type, metalaxyl resistance, potato late-blight, virulence.

\section{Introduction}

Potato late blight, caused by the oomycete Phytophthora infestans (Mont.) de Bary, is one of the most serious potato (Solanum tuberosum L.) diseases in the world, which has been studied for a long time by different plant pathologists worldwide. The disease can cause severe potato famine, as happened in Ireland in 1845 , resulting in the displacement/death of $1 / 3$ of Irish people (Fry, 2008). Despite all the research on $P$. infestans, it remains a major problem in agriculture and one of the worst crop diseases in the world. Control of potato late blight can be achieved by using anti-oomycete fungicides regularly (Cooke et al., 2012), but this is expensive, for example, in Europe, it costs one billion euros (including fungicides and unusable crops) (Haverkort et al., 2008), and the canopy must be treated weekly, when inoculum is already present, and the weather conditions are favourable for disease spread (Lehtinen et al., 2007). In Latvia, potato late-blight is a serious problem for both small-garden and large scale potato growers, who have to apply fungicide to protect plants from infection. For instance, in the vegetation period with favourable weather conditions for late blight development, tuber yield formation was interrupted two weeks earlier in an organic potato production field without any fungicide compared to in a conventional field where fungicide was applied (Skrabule, 2010). Late blight development depends on potato varietal resistance, the foliage of potato varieties with higher resistance were less damaged by late blight, as was also found in Denmark, Estonia, Poland, Lithuania and Latvia (Hansen et al., 2005). Thus, 
it is very important to use only certified seed material of resistant potato varieties and to keep a proper crop rotation (Bimšteine, 2008) thereby reducing spending on fungicides and contamination of the environment and food.

$P$. infestans is heterothallic and can be either A1 or A2 mating type (Drenth et al., 1995). Both mating types can reproduce asexually which is a very fast way for the disease to spread. Yuen and Andersson (2013) reported that, for example, in North and South America, Asia and Africa, P. infestans reproduces mainly asexually. For sexual reproduction it has to produce gametangia and needs both A 1 and $\mathrm{A} 2$ mating types to be present resulting in the production of oospores, which can survive in the soil for up to ten years without a susceptible host (Drenth et al., 1995). Until the early 1980s, the A1 mating type dominated European populations of $P$. infestans (Gisi, Cohen, 1996). The first report in Europe, on mating type A2, was from Switzerland in 1981 (Spielman et al., 1991), but since then, the A2 mating type has been found in almost every European country (Gisi, Cohen, 1996). The "old" population was displaced by the "new" and more aggressive population which resulted in earlier outbreaks of the disease (Fry et al., 1993).

Recent studies in Great Britain have discovered a new aggressive lineage of $P$. infestans, which can overcome host resistance (Cooke et al., 2012). The pathogen has adapted well in different conditions thus securing its survival, for example, in Northern Europe (also in Toluca Valley, Mexico), it has become a soil borne pathogen due to its ability to reproduce sexually (Yuen, Andersson, 2013) and does not need tubers or plant debris to survive over winter. At the same time Kildea et al. (2013) have reported finding P. infestans strains, similar to the former dominant population which had disappeared for more than thirty years (except one finding in 1990s), in Great Britain. Populations of $P$. infestans thus undergo continuous change and scientists face the challenge to outrace the pathogen development.

At present, there is insufficient data on population characteristics of $P$. infestans in Latvia. The identification of $P$. infestans races during 1974-1990 was carried out by the Institute of Phytopathology of Soviet Union (Russia), and the A2 mating type of P. infestans was recorded for the first time in Latvia in 1987 (Bebre et al., 2004). Earlier studies have reported that formation of oospores takes place in Latvian potato fields, but so far, the ratio between mating types $\mathrm{A} 1$ and $\mathrm{A} 2$, is unknown (Bimšteine, 2008).

Potato is a very important food source in Latvia. Potatoes are used mainly for marketing and also for the food industry producing potato chips and starch. Those of lower quality are sometimes used for animal feed (Cudere, 2008). Most farms (97\%) produce potatoes on less than 1 ha and only $0.5 \%$ of farms grow potatoes on more than 5 ha. The average number of treatments against late blight in farms with a plantation size up to 0.5 ha is 1 and in farms with a larger potato area, 3-5 times (Cudere, 2008). The average yield losses in Latvian agroecological conditons are $15-30 \%$, but in favourable years for late blight development, potato yield losses reach 30-60\% (I. Skrabule unpublished data).

Potato late blight has considerable importance in Latvian potato production. Therefore in this study, $P$. infestans isolates collected from Latvia were tested to determine the main characteristics of the late blight pathogen like mating types, metalaxyl resistance and virulence, in order to help develop and optimize control strategies against late blight, and to share this information with scientists (potato breeders), advisors and potato growers. It is also very important to compare populations of $P$. infestans in Latvia with other European populations of the pathogen.

\section{Materials and methods}

Collection and isolation of isolates of Phytophthora infestans. During 2010-2012, 181 isolates of $P$. infestans were collected from different regions and different agro-intensity farms (23 potato fields, from 13 locations) in Latvia (Fig. 1, Table). The late blight samples were collected from large scale conventional farm fields (12), small scale conventional farm fields (6), organic fields (3) and trial fields with breeding lines (2).

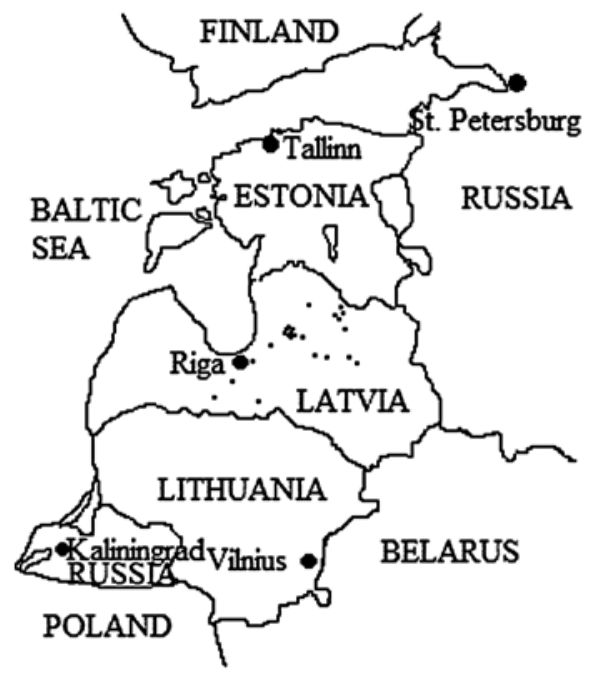

Figure 1. Map of Baltic States and surrounding countries showing the regions in Latvia from which the isolates of Phytophthora infestans were collected during 20102012

All of the isolates were collected from infected leaves, each with a single lesion. All the collected leaflets were placed between washed and sliced potato tubers and transported in cool conditions to the laboratory. Collection of the isolates took place at the beginning of the outbreak of late blight until $97 \%$ of the foliage was destroyed. To culture the pathogen, tubers of the susceptible cultivar 'Berber', without known R-genes were used. Tubers were sterilised in ethanol, flamed and then sliced. Infected leaf tissues were placed between tuber slices, put into sterile Petri dishes and incubated in a growth chamber for 6-7 days at $16^{\circ} \mathrm{C}$. When the mycelia of $P$. infestans had grown through the slice, a small amount of it was taken with a sterile needle, and placed in a sterile Petri dish, filled with rye B agar (Caten, Jinks, 1968). Phenotypic tests were carried out after culturing the pathogen.

Mating type determination. Mating type was determined for 181 isolates (Table) by growing each sample isolate together with the appropriate tester strain (A1 and A2), kindly sent by Asko O. Hannukkala, Natural Resources Institute Finland (Luke), in a Petri dish on rye agar. Plates were assessed after the mycelia had grown together, approximately 14 days after placing the Petri dishes into a growth chamber at $16^{\circ} \mathrm{C}$. Determination 
was carried out under a microscope. Isolates forming oospores on plates with the A1 mating type but not the $\mathrm{A} 2$ were registered as A2; isolates that formed oospores with the A2 mating type but not the A1 were registered as $\mathrm{A} 1$; isolates that formed oospores with the $\mathrm{A} 1$ and the A2 were registered as self-fertile.

Resistance to metalaxyl. Resistance to metalaxyl was tested for 116 isolates (Table), using a modification of the floating-leaflet method (Hermansen et al., 2000). The susceptible cultivar 'Berber' was used for the test. Potato plants were approximately five-six weeks old, when the leaves were taken and disks ( $15 \mathrm{~mm}$ diameter) cut from them with a cork borer. Six leaf disks were floated in Petri plates $(50 \mathrm{~mm})$, each containing $7 \mathrm{ml}$ distilled water or water and metalaxyl solution with concentrations 0.0 ,
10.0 and $100.0 \mathrm{mg} \mathrm{l}^{-1}$. The pathogen's sporangia were taken from Petri dishes, where they were grown in pure cultures on rye B agar, and put into distilled water with a pallet. All the leaf disks were infected with a suspension of sporangia ( $20 \mu \mathrm{l}$ drop). After inoculation, Petri dishes were maintained in the growth chamber at $16^{\circ} \mathrm{C}$ and $90 \%$ relative humidity. The assessment was carried out after seven days by the same parameters as described in Runno-Paurson et al. (2009). The isolates were registered as resistant if they sporulated on leaflets in $100 \mathrm{mg} \mathrm{l}^{-1}$ metalaxyl, intermediate if they sporulated in a metalaxyl concentration of $10 \mathrm{mg} \mathrm{l}^{-1}$ but not on leaves floating on $100 \mathrm{mg} \mathrm{l}^{-1}$, sensitive if they sporulated only in water $(0$ $\mathrm{mg} \mathrm{l}^{-1}$ concentration metalaxyl).

Table. Sampling of Phytophthora infestans isolates collected from different sites in Latvia (2010-2012)

\begin{tabular}{|c|c|c|c|c|c|c|}
\hline \multirow[b]{2}{*}{ Location } & \multirow[b]{2}{*}{ Year } & \multirow{2}{*}{$\begin{array}{l}\text { Number of } \\
\text { fields }\end{array}$} & \multirow{2}{*}{$\begin{array}{c}\text { Number of } \\
\text { isolates }\end{array}$} & \multicolumn{3}{|c|}{ Number of isolates tested for } \\
\hline & & & & mating type & $\begin{array}{l}\text { metalaxyl } \\
\text { resistance }\end{array}$ & virulence \\
\hline Cirulis & 2010 & 1 & 3 & 3 & 3 & 1 \\
\hline Dipeni & 2010 & 1 & 5 & 5 & 2 & 3 \\
\hline Igali & 2010 & 1 & 5 & 5 & 2 & 2 \\
\hline Priekuli & 2010 & 1 & 13 & 13 & 7 & 4 \\
\hline Silmaci & 2010 & 1 & 3 & 3 & 0 & - \\
\hline Vanagi & 2010 & 1 & 7 & 7 & 5 & 2 \\
\hline Dobele & 2011 & 2 & 3 & 3 & 1 & 3 \\
\hline Bauska & 2011 & 2 & 4 & 4 & 2 & 4 \\
\hline Riga & 2011 & 1 & 1 & 1 & 0 & 1 \\
\hline Priekuli & 2011 & 3 & 35 & 35 & 22 & 35 \\
\hline Paukulite & 2011 & 1 & 8 & 8 & 6 & 8 \\
\hline Vijciems & 2011 & 1 & 7 & 7 & 3 & 6 \\
\hline Bilska & 2011 & 1 & 8 & 8 & 6 & 8 \\
\hline Vijciems & 2012 & 1 & 4 & 4 & 4 & 4 \\
\hline Bilska & 2012 & 1 & 8 & 8 & 8 & 8 \\
\hline Priekuli & 2012 & 3 & 53 & 53 & 35 & 53 \\
\hline Dreimani & 2012 & 1 & 14 & 14 & 10 & 14 \\
\hline Total & & 23 & 181 & 181 & 116 & 156 \\
\hline
\end{tabular}

Virulence tests. The specific virulence of 156 isolates (Table) was determined using Black's differential set of potato genotypes containing resistance $(\mathrm{R})$ genes R1-R11 (Malcolmson, Black, 1966) provided by the Scottish Agricultural Science Agency, United Kingdom. Due to technical and logistic reasons, virulence tests were carried out in 2010 only for some of the isolates. Potato leaves were obtained from the differentials grown from meristem plants in the greenhouse. The meristem plants were reproduced by Plant Biotechnological Research Centre EVIKA in Saku, Estonia. Leaves were cut from the plants at 6-8 weeks of age. Filter paper was put in the bottom of plastic trays and moistened with distilled water. Leaves were placed lower side up on the filter paper and each leaflet was inoculated with a $20 \mu \mathrm{l}$ drop of $P$. infestans sporangial suspension $\left(1.0-4.0 \times 10^{4} \mathrm{ml}^{-1}\right.$ sporangia). The trial was carried out in four replications. The plastic trays were covered with polyethylene after the inoculation to maintain high relative humidity and were incubated at $16^{\circ} \mathrm{C}$ with a $16 \mathrm{~h}$ light period. The results were assessed after seven days, using the same scale as indicated for the assessment of metalaxyl resistance.

Data analysis. To test for the effects of year (2010, 2011 or 2012), field type (organic, breeding, small scale conventional or large scale conventional) and their interaction on metalaxyl resistance (metalaxyl-sensitive, intermediate metalaxyl-sensitive or metalaxyl-resistant) and mating type (A1, A2 or self-fertile) multinomial models considering also random effect of site nested to field type were fitted with the $S A S 9.4$ procedure GLIMMIX. As no effects were statistically significant irrespective of considering or not random site effect and the smallest $p$-values corresponded to year and field type interaction indicating potential presence of more specific relationships, we continued with less general studies applying the Fisher exact test to find the associations of metalaxyl resistance and mating type with sampling year by field types and with field types by sampling year. The Fisher exact test was applied also to study the relationships between metalaxyl resistance and mating type.

The race diversity was calculated with the normalized Shannon diversity index. The pairwise comparison of virulence frequencies against different potato R-genes was performed with logistic model ( $S A S$ 9.4 procedure GLIMMIX) considering simultaneously effects of year, field type, their interactions with R-genes and random effect of site nested to field type and followed by the Tukey test for multiple comparison of least square 
means. Associations between virulence to single potato R-gene and metalaxyl resistance, mating type, year and field type were tested for with the Fisher exact test. Each series of $p$-values concerning 11 potato $\mathrm{R}$-genes was corrected for multiple testing using the Holm method.

To discover common patterns in virulence against R-genes hierarchical cluster analysis and principal component analysis were performed. The last was used also to study the relationships of sampling year, field type, mating type and metalaxyl resistance with common virulence patterns. Fisher exact tests and all multivariate analyses were performed with statistical software $R 3.1 .1$, for principal component analysis package ade 4 was applied. Test results with $p<0.05$ were considered statistically significant.

\section{Results}

Mating type. Of the 181 isolates tested, $52.5 \%$ were A1, $43.1 \%$ - A 2 and $4.4 \%$ - self-fertile mating type. The distribution of mating types did not differ between years $(p=0.55)$ or between field types ( $p=0.40)$ (Fig. 2 ). The interaction effect of year and field type was on the limit but still statistically non-significant $(p=0.060)$.

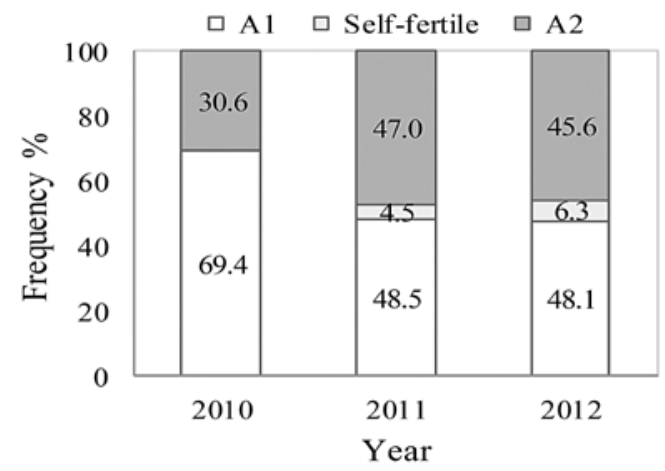

Figure 2. Frequency of mating types in Latvia (20102012)

However, omitting the year 2010, where no breeding and organic fields were presented, a statistically significant association between mating type and field type was found $(p=0.004)$ - if A1 mating type had almost the same frequency in all type of fields, then A2 mating type was found mostly in large scale conventional fields (56.7\% of findings). Comparison of years 2011 and 2012 revealed that this association between mating type and field type persisted in general but with some changes. In 2011, the A1 mating type was found most frequently in large scale conventional fields and less frequently in organic fields ( $40.6 \%$ and $9.4 \%$ of findings, respectively), whereas in 2012 , the opposite occurred with $31.5 \%$ of findings from organic fields and only $15.8 \%$ from large scale conventional fields. The A2 mating type was most frequently found in large scale conventional fields in both years, but the frequencies differed quite a lot $(45.2 \%$ and $66.7 \%$ in 2011 and 2012, respectively). In 2011, 29.0\% of A2 mating types were from breeding fields, but in 2012, only $5.6 \%$ of A2 findings came from such fields. The self-fertile mating type was found only in small and large scale conventional fields.

Metalaxyl resistance. Of the 116 isolates screened for resistance to metalaxyl, $25.9 \%$ were resistant, $19.8 \%$ intermediate and $54.3 \%$ sensitive to metalaxyl. Although these proportions varied with year, the association between metalaxyl resistance and year was not statistically significant $(p=0.21)$ (Fig. 3).

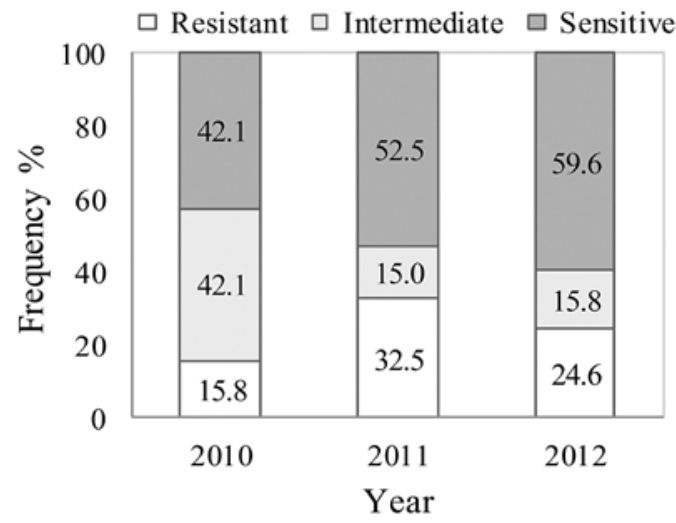

Figure 3. Metalaxyl resistance among isolates of Phytophthora infestans in Latvia (2010-2012)

Metalaxyl resistant strains were absent from seven fields, five of which were large scale conventional fields, one a small scale conventional and one an organic field. Sensitive strains were absent from four fields, from one organic field and three large scale conventional fields. The distribution of metalaxyl resistance was quite similar over different field types $(p=0.66)$ and this tendency did not depend on year $(p=0.13)$.

The percentage of sensitive isolates was the highest among mating type A1 and the percentage of resistant isolates among mating type A2 (Fig. 4). However, this association was not statistically significant ( $p=$ 0.093). But leaving out the self-fertile mating type with only three isolates screened for resistance to metalaxyl resulted in significant association between mating type and metalaxyl resistance $(p=0.044)$. Studying the association by years revealed that the statistically significant association was found only in 2012 ( $p=$ 0.006 and $p=0.003$, respectively considering and not the self-fertile mating type). Studying the distribution of metalaxyl resistance over years by mating types revealed a statistically significant change for mating type A1 ( $p=$ $0.014)$ but not for mating type A2 $(p=0.56)$.

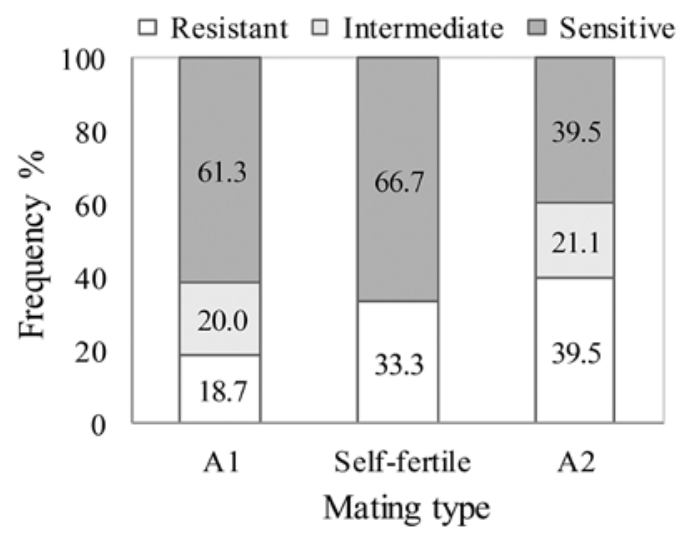

Figure 4. Metalaxyl resistance among isolates with different mating type in Latvia (2010-2012)

Virulence. Of the 156 isolates analysed for virulence, $4(2.6 \%)$ were not virulent against any R-genes and $12(7.7 \%)$ were virulent against all 11 R-genes. More 
than $80 \%$ of isolates were virulent to R1, R3, R4, R7, $\mathrm{R} 10$ and R11, while $33 \%$ or less isolates were virulent to $\mathrm{R} 5, \mathrm{R} 8$ and $\mathrm{R} 9$. The least frequent was virulence against R9 with $24 \%$ of isolates. In total 69 different pathotypes were detected and $94.1 \%$ of isolates were virulent against four or more R-genes. At the same time, the four most common pathotypes made up $33.6 \%$ of isolates and no pathotypes exceeded $10 \%$ of isolates. The most common races were 1.2.3.4.7.10.11 (15 isolates) and 1.2.3.4.6.7.10.11 (13 isolates). The normalized Shannon diversity index was 0.73 .

The virulence to specific R-genes was statistically significantly different $(p<0.001)$ (Fig. 5). Also, the overall virulence was statistically significantly different between years $(p<0.001)$ being lower in 2010 and higher in 2012 , but not between field types $(p=0.88)$. The R-genes interaction effects with year and field type were statistically significant (both $p<0.001$ ), indicating that there existed a difference between virulence to specific $\mathrm{R}$-genes in different years and field types. Results of Fisher exact tests followed by Holm correction for multiple testing revealed, that the proportions of isolates virulent to R6 and R9 were statistically significantly different in 2011 and 2012 ( $p=0.013$ and $p=0.001$, respectively). The virulence against the same R-genes was different also at different field types $(p=0.001$ and $p<0.001$, respectively), whereby the resistance against both R6 and R9 was more common in 2011 and in organic fields.

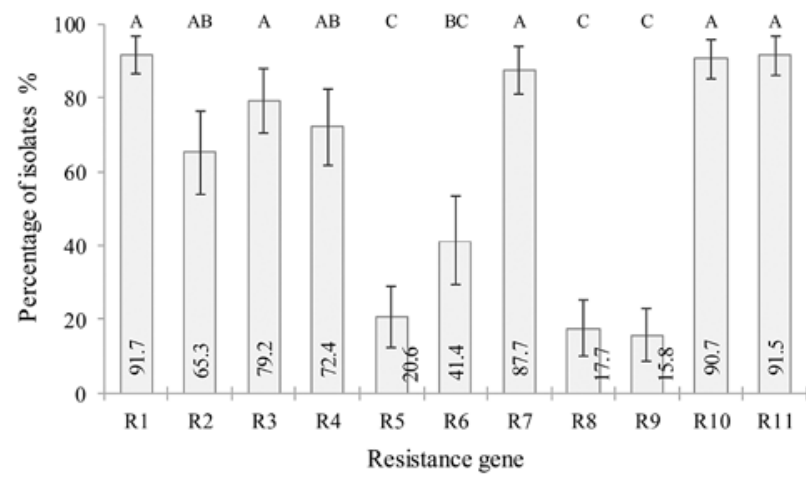

Note. Percentages with different letters are statistically significantly different $(p<0.05)$; logistic model considering also effects of year and field type followed by Tukey test for multiple comparison of least square means.

Figure 5. Estimated frequency ( \pm standard error) of virulence to potato R-genes of Phytophthora infestans population in Latvia (2010-2012)

There were no statistically significant relationships between virulence to different R-genes and metalaxyl resistance. Four (R3, R7, R9 and R11) R-genes showed statistically significantly different proportions of virulence among mating types, but only two of these relationships remained statistically significant after correction for multiple testing ( $\mathrm{R} 3-p=0.011, \mathrm{R} 7-p=$ 0.003 ) showing higher virulence among A1 isolates.

The hierarchical cluster analysis of virulence against R-genes shows that two groups of genes exist - one group consisting of three R-genes with less frequent virulence (R5, R8 and R9) and the second group containing other R-genes (Fig. 6). Among the latter, the closest R-genes to the first group are R6 and R2 with intermediate frequency of virulence. This result indicates that if an isolate is virulent against one rare R-gene, it is quite often also virulent against another rare R-gene and also the virulence against more common R-genes tend to exist simultaneously.

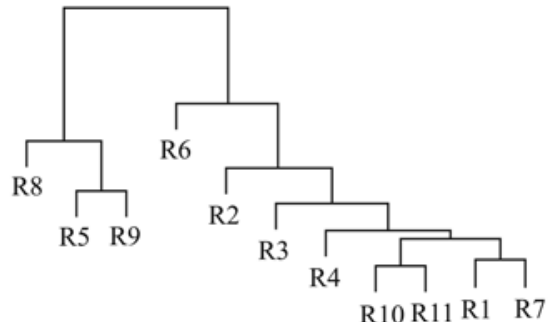

Figure 6. Dendrogram of potato R-genes according to hierarchical clustering

The first two principal components describe $44.7 \%$ of total variability of virulence against different R-genes. The most common pattern (the first principal component) distinguishes less and more virulent isolates (Fig. 7) and the second pattern distinguishes isolates virulent against less and more common R-genes.

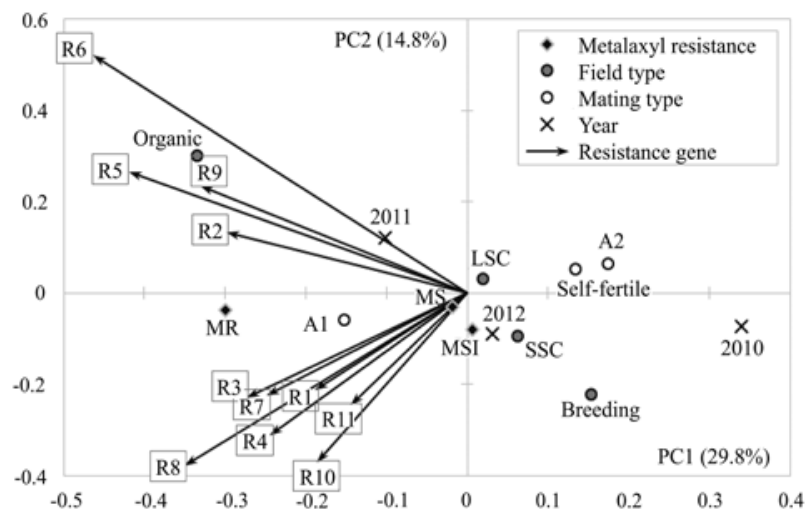

Note. Arrows correspond to factor loadings relating the first two principal components with R-genes and markers denote the average scores corresponding to different values of metalaxyl resistance (MS - metalaxyl-sensitive, MSI - intermediate metalaxyl-sensitive, MR - metalaxyl-resistant), field type (SSC - small scale conventional, LSC - large scale conventional), mating type (A1, A2 and self-fertile) and year (2010-2012).

Figure 7. Results of principal component analysis of R-genes

The analysis of principal components' values (scores) shows that the virulence was generally more frequent in organic fields and among A1 and metalaxylresistant isolates and less frequent in 2010 . The virulence against more rare R-genes appeared more frequently in organic fields and in 2011 and less frequently in breeding fields and among intermediate metalaxyl-sensitive isolates.

\section{Discussion}

Phytophthora infestans isolates, collected from different regions and different agro-intensity farms in Latvia, were tested to determine the main characteristics of the late blight pathogen and to compare populations of $P$. infestans in Latvia with other European populations of the pathogen. In our study, we found that the mating type A1:A2 ratio in 2011 and 2012 was close to 1:1, which is perfect for sexual reproduction and formation 
of oospores to take place (Turkensteen et al., 2000). This can be a direct threat to the strategies used to prevent late blight disease and to fight against the pathogen, because it becomes a soil-borne inoculum (Yuen, Andersson, 2013). The percentage of A1 mating type was higher than the incidence of A2 mating type for all three years. This result is similar to data from Estonia in 2001-2007 (Runno-Paurson et al., 2012) and from Lithuania in 2010-2011 (Runno-Paurson et al., 2015). In 20042007, the proportion (A1:A2:self-fertile) in Estonia was 64:33:3 (Runno-Paurson et al., 2010), which is close to the results in Latvia in 2010. The lower proportion of A2 mating type in 1998-2002 has also been reported in Ireland (Cooke et al., 2006), but, in 2009 and 2010, the numbers were totally different - nearly $60 \%$ and $75 \%$, respectively, were A2 mating type (Cooke et al., 2012). In our study, A2 mating type was found mostly in large scale conventional fields - the direct opposite result to Estonian studies, where the proportion of A2 mating type was significantly higher in small scale conventional fields (Runno-Paurson et al., 2010). The spreading of A2 mating type poses a threat to sustainable potato production, because it is able to overcome previously late blight resistant varieties (Cooke et al., 2012). The fact that both A1 and A2 mating types are present in most of the studied Latvian fields can lead to soil contamination with oospores so it is very important to maintain the crop rotation system, to prevent early outbreaks of the disease. All this data supports the evidence that the northern population of $P$. infestans in Europe along with Baltic countries Latvia and Estonia (Runno-Paurson et al., 2014) can be called the second centre of sexual reproduction of P. infestans (Yuen, Andersson, 2013). The first finding of oospores in Latvia took place in the 1980s, but the research was discontinued. After that, the occurrence of oospores on potato leaves in Latvia was investigated during 2002-2004. In 80-94\% of the investigated cases, oospores were found. Most of the oospores were formed on the potato plants in private gardens, where potatoes had been cultivated for many years, and the lowest frequency of oospores was in a certified organic field, where over twenty years other crops had been grown (Bimšteine, 2008). However, there was no information about the ratio of the two mating types.

Our results showed, that isolates sensitive to metalaxyl, were predominant. The results were similar to those obtained in the Nordic countries - Norway, Sweden, Finland and Denmark (Lehtinen et al., 2008) and Poland, where $58.3 \%$ of isolates were sensitive in 2006 (Chmielarz et al., 2014), and in 2007-2009, the proportion of metalaxyl-sensitive strains reached $75 \%$. Isolates sensitive to metalaxyl dominated also in Lithuania in 2010-2012 (Runno-Paurson et al., 2015) and in 2011 as well as 2013 , over $50 \%$ of tested isolates were sensitive to metalaxyl in Northern Ireland (www. eucablight.org). Nevertheless, opposite results have been reported in Ireland either (in 2009), where metalaxylresistant isolates dominated both populations - in the Republic of Ireland and in the Northern Ireland, and in France, where the frequency of metalaxyl-resistant strains reached $75 \%$ (www.eucablight.org). More stable results were reported in Estonia during 2004-2007, where the proportion of resistant-intermediate-sensitive strains was 37:25:37 percentages, respectively, but still, in 2007, metalaxyl-sensitive strains dominated the population.
Another resemblance with the Estonian study is the fact that most of the metalaxyl-resistant isolates were A2 mating type (Runno-Paurson et al., 2010). The amount of metalaxyl-resistant strains of $P$. infestans in Latvia may indicate low usage of fungicides on the fields from which the samples were collected. For example, in Finland, the proportion of metalaxyl-based products is less than $10 \%$ of all fungicides used to prevent late blight (Hannukkala et al., 2007) and at the same time, in Estonia, metalaxylbased fungicides are widely used (Runno-Paurson et al., 2014). In Denmark, metalaxyl-M is not registered for commercial use at all (Lehtinen et al., 2008).

In this study, we found 69 different pathotypes among the 156 isolates tested. In total $34.6 \%$ of the races were unique and found only from one isolate. The result is similar to Estonian studies in 2002-2003, where nearly half of the pathotypes were found only once (Runno-Paurson et al., 2009). The mean number of virulence factors per isolate was as high as 7.2. Twelve isolates were virulent to all R-gene differentials(1.2.3.4.5.6.7.8.9.10.11). In Finland (1997-2000), only one similar isolate was found, and, at the same time, the most common race 1.3.4.7.8.10.11 in Finland (Lehtinen et al., 2007) and in Estonia (20022003) (Runno-Paurson et al., 2009), was not found in Latvia. The most common races were 1.2.3.4.7.10.11 (15 strains) and 1.2.3.4.6.7.10.11 (13 strains), whereas the dominating race 1.3.4.7.10.11 in Europe and in Nordic countries was found only five times. Complex races are also common in Polish populations (Chmielarz et al., 2014), a similar situation to that in Russia (Statsyuk et al., 2013) and in Estonia (Runno-Paurson et al., 2009; $2010 ; 2013 ; 2014)$. Frequency of virulence against R2 gene has been rare in European countries like Poland, Denmark, Finland, Norway and Sweden (Lehtinen et al., 2008; Chmielarz et al., 2014), but it is relatively high in Latvia, where $76 \%$ of the isolates were able to overcome the R-gene. Virulence factors R5 (27\%), R8 (32\%) and R9 $(24 \%)$ were rare, but the incidence of those R-genes was still comparatively high when compared with results reported in Estonian populations in 2001-2007, where only $9 \%$ of the isolates were virulent to R5 and $11 \%$ to R9 (Runno-Paurson et al., 2013). To compare our results with research done in the 1960s and 1970s, there have been major changes considering $P$. infestans races in Latvian populations - predominant races 1, 4 and 1.4 were replaced in less than twenty years with more complex races 4.10.11, 1.4.7.8.10.11, 1.3.4.7.8.10.11 and 1.2.3.4.7.8.10.11 (Bebre et al., 2004), as in most European populations. Yuen and Andersson (2013) reported that using specific resistance (R) genes, as a preventative method against $P$. infestans, can be useless due to the pathogen's evolutionary potential to break through the resistance created with these genes, but this study showed that there are still a few (R5, R8 and R9) R-genes that may be useful if used in parallel with other protective methods.

Our study indicated that the Latvian population of $P$. infestans is diverse. The proportion of mating types and the occurrence of both A1 and A2 in the same field indicate the possibility of sexual recombination in Latvian fields. Due to this, it is very important to keep the crop rotation system, to prevent soil contamination with long-living oospores. The Latvian population of $P$. infestans shares many similarities with other European populations suggesting gene flow between populations. 


\section{Conclusions}

1. The Latvian population of Phytophthora infestans is diverse. The proportion of mating types and the occurrence of both A1 and A2 in the same field indicate the possibility of sexual recombination in Latvian fields; therefore, it is essential to keep the crop rotation system to prevent soil contamination with oospores and early outbreaks of the disease in the fields.

2. Isolates sensitive to metalaxyl were predominant but were still absent from four (one organic and three large scale conventional) fields. About one fourth of the studied strains were resistant to metalaxyl.

3. A little more than one third of races found were unique and the mean number of virulences per isolate was 7.2. Twelve isolates were able to overcome all $11(1.2 .3 .4 .5 .6 .7 .8 .9 .10 .11)$ resistance $(\mathrm{R})$ genes and the dominating race 1.3.4.7.10.11 in Europe and in Nordic countries was found only five times.

4. Latvian population of $P$. infestans shares many similarities with other European populations, which suggests gene flow between populations.

\section{Acknowledgements}

The authors thank M. Hansen, K. Jõgi, L. Laane and H. Nassar from Estonian University of Life Sciences and K. Liiv from Estonian Research Institute of Agriculture for technical assistance. The study was supported by Estonian Foundation grant No. 9432; Target Financing SF170057s09, Institutional research funding IUT36-2 of the Estonian Ministry of Education and project RESIST 3.2.0701.11-0003.

Received 02032015

Accepted 03072015

\section{References}

Bebre G., Skrabule I., Osa M. 2004. The distribution and changes of Phytophthora infestans population in Latvia. Plant Breeding and Seed Science, 50: 43-49

Bimšteine G. 2008. Phytophthora infestans populations in Latvia. Proceedings of the Latvian Academy of Sciences. Section B. Natural, Exact, and Applied Sciences, 62 (6): 223-226 http://dx.doi.org/10.2478/v10046-009-0004-y

Caten C. E., Jinks J. L. 1968. Spontaneous variability of single isolates of Phytophthora infestans. I. Cultural variation. Canadian Journal of Botany, 46: 329-348 http://dx.doi.org/10.1139/b68-055

Chmielarz M., Sobkowiak S., Debski K., Cooke D. E. L., Brurberg M. B., Śliwka J. 2014. Diversity of Phytophthora infestans from Poland. Plant Pathology, 63 (1): 203-2011 http://dx.doi.org/10.1111/ppa.12076

Cooke D. E. L., Cano L. M., Raffaele S., Bain R. A., Cooke L. R., Etherington G. J., Deahl K. L., Farrer R. A., Gilroy E. M., Goss E. M., Grünwald N. J., Hein I., MacLean D., McNicol J. W., Randall E., Oliva R. F., Pel M. A., Shaw D. S., Squires J. N., Taylor M. C., Vleeshouwers V. G. A. A., Birch P. R. J., Lees A. K., Kamoun S. 2012. Genome analyses of an aggressive and invasive lineage of the Irish potato famine pathogen. PLOS Pathogens, 8 (10): e1002940 http://dx.doi.org/10.1371/journal.ppat.1002940

Cooke L. R., Carlisle D. J., Donaghy C., Quinn M., Perez F. M., Deahl K. L. 2006. The Northern Ireland Phytophthora infestans population 1998-2002 characterized by genotypic and phenotypic markers. Plant Pathology, 55 (3): 320-330 http://dx.doi.org/10.1111/j.1365-3059.2006.01335.x
Cudere R. 2008. Impact of the current proposals on potato production solutions in Latvia. EPPO Workshop on sustainable pest control and fewer active substances $<\mathrm{http}$ ://archives.eppo. int/MEETINGS/2008 conferences/active substances/08 Cudere/cudere1.HTM $>$ [accessed $0203201 \overline{5}$ ]

Drenth A., Jassen E. M., Govers F. 1995. Formation and survival of oospores of Phytophthora infestans under natural conditions. Plant Pathology. 44 (1): 86-94 http://dx.doi.org/10.1111/j.1365-3059.1995.tb02719.x

Fry W. 2008. Phytophthora infestans: the plant (and R gene) destroyer. Molecular Plant Pathology. 9 (3): 385-402 http://dx.doi.org/10.1111/j.1364-3703.2007.00465.x

Fry W. E., Goodwin S. B., Dyer A. T., Matuszak J. M., Drenth A., Tooley P. W., Sujkowski L. S., Koh Y. J., Cohen B. A., Spielman L. J., Deahl K. L., Inglis D. A., Sandlan K. P. 1993. Historical and recent migrations of Phytophthora infestans: chronology, pathways, and implications. Plant Disease. 77: 653-661 http://dx.doi.org/10.1094/PD-77-0653

Gisi U., Cohen Y. 1996. Resistance to phenylamide fungicides: a case study with Phytophthora infestans involving mating type and race structure. Annual Review of Phytopathology, 34: 549-572 http://dx.doi.org/10.1146/annurev.phyto.34.1.549

Hannukkala A. O., Kaukoranta T., Lehtinen A., Rahkonen A. 2007. Late-blight epidemics on potato in Finland, 19332002; increased and earlier occurrence of epidemics associated with climate change and lack of rotation. Plant Pathology. 56 (1): 167-176 http://dx.doi.org/10.1111/j.1365-3059.2006.01451.x

Hansen J. G., Koppel M., Valskyte A., Turka I., Kapsa J. 2005. Evaluation of foliar resistance in potato to Phytophthora infestans based on an international field trial network. Plant Pathology, 54 (2): 169-179 http://dx.doi.org/10.1111/j.1365-3059.2005.01166.x

Haverkort A. J., Boonekamp P. M., Hutten R., Jacobsen E., Lotz L. A. P., Kessel G. J. T., Visser R. G. F., van der Vossen E. A. G. 2008. Societal costs of late blight in potato and prospects of durable resistance through cisgenic modification. Potato Research. 51: 47-57 http://dx.doi.org/10.1007/s11540-008-9089-y

Hermansen A., Hannukkala A., Hafskjold Naerstad R., Brurberg M. B. 2000. Variation in populations of Phytophthora infestans in Finland and Norway: mating type, metalaxyl resistance and virulence phenotype. Plant Pathology. 49 (1): 11-22 http://dx.doi.org/10.1046/j.1365-3059.2000.00426.x

Kildea S., Quinn L., Mehenni-Ciz J., Cooke D. E. L., Perez F. M., Deahl K. L., Griffin D., Cooke L. R. 2013. Re-emergence of the $I b$ mitochondrial haplotype within the British and Irish Phytophthora infestans populations. European Journal of Plant Pathology, 135: 237-242 http://dx.doi.org/10.1007/s10658-012-0098-y

Lehtinen A., Hannukkala A., Rantanen T., Jauhiainen L. 2007. Phenotypic and genetic variation in Finnish potato-late blight populations, 1997-2000. Plant Pathology, 56 (3): $480-491$ http://dx.doi.org/10.1111/j.1365-3059.2006.01556.x

Lehtinen A., Hannukkala A., Andersson B., Hermansen A., Le V. H., Naerstad R., Brurberg M. B., Nielsen B. J., Hansen J. G., Yuen J. 2008. Phenotypic variation in Nordic populations of Phytophthora infestans in 2003. Plant Pathology. 57 (2): 227-234

http://dx.doi.org/10.1111/j.1365-3059.2007.01739.x

Malcolmson J. F., Black W. 1966. New R genes in Solanum demissum Lindl. And their complementary races of Phytophthora infestans (Mont.) de Bary. Euphytica, 15: 199-203 http://dx.doi.org/10.1007/BF00022324

Runno-Paurson E., Fry W. E., Myers K. L., Koppel M., Mänd M. 2009. Characterization of Phytophthora infestans isolates collected from potato in Estonia during 2002-2003. European Journal of Plant Pathology, 124 (4): 565-575 http://dx.doi.org/10.1007/s10658-009-9442-2 
Runno-Paurson E., Fry W. E., Remmel T., Mänd M., Myers K. L. 2010. Phenotypic and genotypic characterisation of Estonian Isolates of Phytophthora infestans in 2004-2007. Journal of Plant Pathology, 92 (2): 381-390

Runno-Paurson E., Hannukkala A., Williams I., Koppel M., Mänd M. 2012. The structure of mating type, virulence, metalaxyl resistance of Phytophthora infestans in a longterm phenotypic study in distinct location in Eastern Estonia. Journal of Plant Diseases and Protection, 119: 45-52

Runno-Paurson E., Hannukkala A. O., Kotkas K., Koppel M., Williams I. H., Mänd M. 2013. Impact of phytosanitary quality of seed potato and temporal epidemic progress on the phenotypic diversity of Phytophthora infestans populations. American Journal of Potato Research, 90: 245-254 http://dx.doi.org/10.1007/s12230-013-9299-y

Runno-Paurson E., Hannukkala A., Kotkas K., Koppel M., Williams I. H., Mänd M. 2014. Population changes and phenotypic diversity of Phytophthora infestans isolates from Estonia and Finland. Journal of Plant Pathology, 96 (1): 85-95

Runno-Paurson E., Ronis A., Hansen M., Aav A., Williams I. H. 2015. Lithuanian populations of Phytophthora infestans revealed a high phenotypic diversity. Journal of Plant Diseases and Protection, 122 (2): 57-65
Turkensteen L. J., Flier W. G., Wanningen R., Mulder A. 2000. Production, survival and infectivity of oospores of Phytophthora infestans. Plant Pathology, 49 (6): 688-696 http://dx.doi.org/10.1046/j.1365-3059.2000.00515.x

Skrabule I. 2010. Evaluation of potato breeding clones in organic and conventional growing conditions. Proceedings of EUCARPIA $2^{\text {nd }}$ conference of the Organic and Lowinput Agriculture section. Paris, France, p. 102-105

Spielman L. J., Drenth A., Davidse L. C., Sujkowski L. J., Gu W.,Tooley P. W., Fry W. E. 1991. A second world-wide migration and population displacement of Phtyophthora infestans. Plant Pathology, 40 (3): 422-430 http://dx.doi.org/10.1111/j.1365-3059.1991.tb02400.x

Statsyuk N. V., Semina Y. V., Perez F. G. M., Larsen M. M., Kuznetsova I. N., Morozova E. V., Deahl K. L., Grünwald N. J. 2013. Characterization of Russian Phytophthora infestans populations: DNA fingerprinting and SSR analysis. PPO-Special Report, 16: 255-266

Yuen J. E., Andersson B. 2013. What is the evidence for sexual reproduction of Phytophthora infestans in Europe? Plant Pathology, 62 (3): 485-491 http://dx.doi.org/10.1111/j.1365-3059.2012.02685.x

ISSN 1392-3196 / e-ISSN 2335-8947

Zemdirbyste-Agriculture, vol. 102, No. 3 (2015), p. 335-342

DOI $10.13080 /$ z-a.2015.102.043

\title{
Phytophthora infestans izoliatų, surinktų Latvijoje, dauginimosi tipo struktūra, atsparumas metalaksilui ir virulentiškumas
}

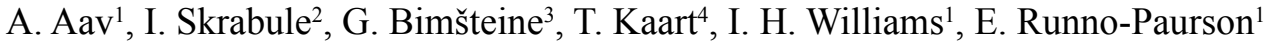 \\ ${ }^{1}$ Estijos gyvybès mokslų universiteto Žemès ūkio ir aplinkos mokslų institutas \\ ${ }^{2}$ Priekulès augalụ selekcijos institutas, Latvija \\ ${ }^{3}$ Latvijos žemès ūkio universiteto Dirvožemio ir augalininkystes mokslų institutas \\ ${ }^{4}$ Estijos gyvybès mokslų universiteto Veterinarinès medicinos ir gyvulininkystės mokslų institutas
}

\section{Santrauka}

Bulvių maras, sukeltas oomicetų Phytophthora infestans (Mont.) de Bary, yra viena grèsmingiausių bulvių ligų, dèl kurios patiriami dideli derliaus nuostoliai visame pasaulyje, taip pat ir Latvijoje. Šiuo metu yra nedaug duomenų apie $P$. infestans populiacijos ypatybes Latvijoje. Todèl pagrindinis tyrimo tikslas - surinkti naujų duomenų apie Latvijos P. infestans izoliatus, taip pat naudojant Black’o diferencialų rinkinį, kurị sudaro R1-R11 atsparumo genų, nustatyti svarbiausias šio patogeno savybes, ypač dauginimosi tipą, atsparumą metalaksilui ir virulentiškumą. 2010-2012 m. iš 13 Latvijos vietovių ir 23 bulvių laukų buvo surinktas 181 P. infestans izoliatas. Iš 181 tirtų izoliatu $52,5 \%$ buvo A1, 43,1 \% - A2 ir 4,4\% - nelytinio dauginimosi tipo. Iš 116 izoliatų, tirtų dèl atsparumo metalaksilui, 25,9 \% buvo atsparūs, 19,8 \% -vidutiniškai atsparūs ir 54,3 \% - jautrūs. Daugiau nei 80 \% izoliatų buvo virulentški R1, R3, R4, R7, R10 ir R11, o $33 \%$ ar mažiau izoliatų - R5, R8 ir R9 genams. Rečiausias virulentiškumas R9 genui buvo nustatytas $24 \%$ izoliatu. Tyrimas atskleidè, kad Latvijos $P$. infestans populiacija yra nevienoda. Dauginimosi tipų proporcija ir A1 bei A2 tipų pasiskirstymas tame pačiame lauke rodo lytinès rekombinacijos galimybę Latvijoje. Todèl, siekiant išvengti užsikrètimo ilgaamžèmis oosporomis, yra labai svarbu laikytis sejomainos. Latvijos $P$. infestans populiacija turi daug panašumų su kitomis Europoje pasitaikančiomis populiacijomis, o tai rodo genų plitimą tarp populiacijų.

Reikšminiai žodžiai: atsparumas metalaksilui, bulvių maras, dauginimosi tipas, virulentiškumas. 